\title{
Carbon and Nitrogen Stocks and C: N Ratio of Harran Plain Soils
}

\author{
Erdal SAKIN ${ }^{1)}$, Aise DELIBORAN ${ }^{2)}$, Elif Didem SAKIN ${ }^{11}$, Hasan ASLAN ${ }^{21}$ \\ ${ }^{1)}$ University of Harran, Faculty of Agriculture Department of Soil Science and Plant Nutrition, \\ Campus of Osmanbey Sanliurfa, Turkey; esakin@harran.edu.tr \\ ${ }^{2)}$ Directorate of GAP Soil-Water Researhes and Agriculture Research Institute, Sanliurfa; Turkey
}

\begin{abstract}
Previous studies have focused on carbon $(\mathrm{C})$ and nitrogen $(\mathrm{N})$ stocks of soils because of increases in atmospheric carbon dioxide $\left(\mathrm{CO}_{2}\right)$ and terrestrial ecosystems with wide $\mathrm{N}$ storages. The goal of this study is to determine $\mathrm{C}$ amounts and stocks that are important for global warming, $\mathrm{N}$ amounts and stocks and $\mathrm{C}: \mathrm{N}$ ratios. To this end, 16 series were opened on the Harran Plain and soil samples were taken from $100 \mathrm{~cm}$ depth and each horizon. The results showed that average carbon amounts changed between 3.61 and $6.47 \mathrm{~kg} \mathrm{C} \mathrm{m}^{-2}$. $\mathrm{N}$ amounts were between 0.18 and $0.34 \mathrm{~kg} \mathrm{C} \mathrm{m}^{-2}, \mathrm{C}: \mathrm{N}$ ratios were between $4.34: 1$ and 6.04:1 and bulk density (BD) was $1.23-1.34 \mathrm{Mg}$ $\mathrm{m}^{-3}$. Carbon and $\mathrm{N}$ stocks were determined as $10.53 \mathrm{Tg} \mathrm{C}$ and $1.96 \mathrm{Tg} \mathrm{N}$, respectively. Student's $\mathrm{t}$-test was used on all data comparisons and equation determinations, and data were examined at $\mathrm{p}<0.05$ and $\mathrm{p}<0.01$ importance levels.
\end{abstract}

Keywords: Carbon cycle, nitrogen cycle, nitrogen, carbon, C:N ratios

\section{Introduction}

The importance of the biogeochemical cycles of carbon and nitrogen has increased in terrestrial ecosystems throughout world because their oxidation into the atmosphere plays an important role in global warming maintenance. Soil organic carbon (SOC) is the largest component of terrestrial carbon, and the amount of carbon that exists as SOC is two to three times greater than the carbon present in live vegetation (Post and Kwon, 2000). Moreover, changes in SOC pools can increase the carbon dioxide $\left(\mathrm{CO}_{2}\right)$ concentrations in the atmosphere (Smith, 2008). Therefore, understanding soil carbon storage potential and developing effective methods to decrease the atmospheric $\mathrm{CO}_{2}$ concentration are vitally important $(\mathrm{Fu}$ et al., 2010).

Many factors affect the biogeochemical cycle of SOC and therefore also affect SOC stocks and distribution. One of the most important factors is land-use alteration. While converting natural forest areas and meadows to farming areas affects SOC stocks in different ways in different ecosystems and regions (Solomon et al., 2000; Rodriguez-Murillo, 2001; Powers, 2004; Yimer et al., 2007), cultivation and other deformations cause approximately $40 \mathrm{Pg}$ of C loss. Nearly 1.6 Pg C y ${ }^{-1}$ were released in the 1990s (Smith, 2008). Developing non- cultivated agriculture techniques can decreases SOC pool decrease which emerged as a result of natural and forest areas decrease (Puget and Lal, 2005; Grandy and Robertson, 2007).

Soil is one of the most important $\mathrm{C}$ and $\mathrm{N}$ pools and includes approximately 75\% OC and 95\% N (Schlesinger, 1997). The interaction between SOC and $N$ is affected by the plants that are present, which affects the ecosystem yield and the terrestrial C cycle. Numerical models of $\mathrm{C}$ and $\mathrm{N}$ cycles include terms for the climate, the atmosphere and land-use alternation (Homann et al., 2000; Kirschbaum, 2000; Pepper et al., 2005). Jenny (1941) synthesised and summarised the interaction between climate and soil humidity. According to her study, when humidity increases, the $\mathrm{N}$ ratio in soil increases in the meadows in the central and eastern United States, but the effects on forests are minor. The $\mathrm{N}$ ratio in soil also increases when the temperature increases. Sandy soils contain less mineral-organic $\mathrm{C}$ and $\mathrm{N}$ than loamy soils. The $\mathrm{C}: \mathrm{N}$ ratio of sandy soils is higher than that of loamy soils. Similar studies were conducted simultaneously in the central United States (Burke et al., 1989; Franzmeier et al., 1985; Sims and Nielsen 1986), as well as in other parts of the country (Conant et al., 1998; Grigal and Ohmann, 1992; Homann et al., 2004) and in other countries of the world (Hontaria et al., 1999; Paruello, 1998). The results showed differing trends. Although it was expected that SOC would increase with temperature decreases, SOC decreased in southern Oregon (Homann et al., 1995) and Finland forests (Liski and Westman, 1997). Whereas it was expected that SOC and $\mathrm{N}$ stocks would increase with precipitation increases (Spain, 1990). These different trends were caused by climate regimes, seasonal weather differences, altitude differences and other factors (Homann et al., 2007).

Biomass accumulates as a result of the autotrophic synthesis of organic compounds on live plants. These processes show that live and dead organic materials contain $\mathrm{C}$ and $\mathrm{N}$ elements. Because of this relationship, the $\mathrm{C}: \mathrm{N}$ ratio has been used to characterise live and dead organic matter. Total $\mathrm{C}$ accumulation in biomass is generally limited by the effective $\mathrm{N}$ (Melillo, 1981; Aber et al., 1989). If the effective $\mathrm{N}$ increases, biomass increases and therefore C fixation increases (Mäkipää et al., 1999). 
In studying ecosystem stability, it is important worldwide to determine $\mathrm{C}: \mathrm{N}$ ratios and create data banks of the results because this ratio serves as an indicator of stability. The goal of this study was to determine the $\mathrm{C}$ and $\mathrm{N}$ stocks, the $\mathrm{C}: \mathrm{N}$ ratios and the relationship between $\mathrm{C}$ and $\mathrm{N}$ in the Harran Plain soils that cover 225000 ha.

\section{Materials and methods}

The Harran Plain is located in the Southeast Anatolia Region, between $38^{\circ} 48^{\prime}$ to $39^{\circ} 12^{\prime}$ E longitude and $37^{\circ} 09^{\prime}$ to $36^{\circ} 42^{\prime} \mathrm{N}$ latitude, and it covers 225000 ha in area. Arid and semi-arid soils were opened to irrigation there in 1995. In general, the Harran plains descend to the south; one plain, whose three sides are surrounded with mountains, creating a pot-like appearance, is depicted in Fig. 1. The area between Harran and Akcakale has the lowest elevation. Dinc et al. (1998) detected 25 soil series on Harran plain According to the studies of the Soil Survey Staff (1975), FAO/UNESCO (1974) and Dinc et al. (1988), the plain soils are of the Entisol, Vertisol and Aridisol soil orders. The soil group details of the Harran plain soils are provided in Tab. 1. Studies showed that the Bellitas (5), İkizce (7) and Cekcek (2) series are of the Entisol order; the Bozyazı (12), Ugurlu (1), Begdes (10), Akcakale (15) and Kisas (4) series are of the Vertisol order; and the Gurgelen (6), Ekinyazı (14), Akoren (13), Irice

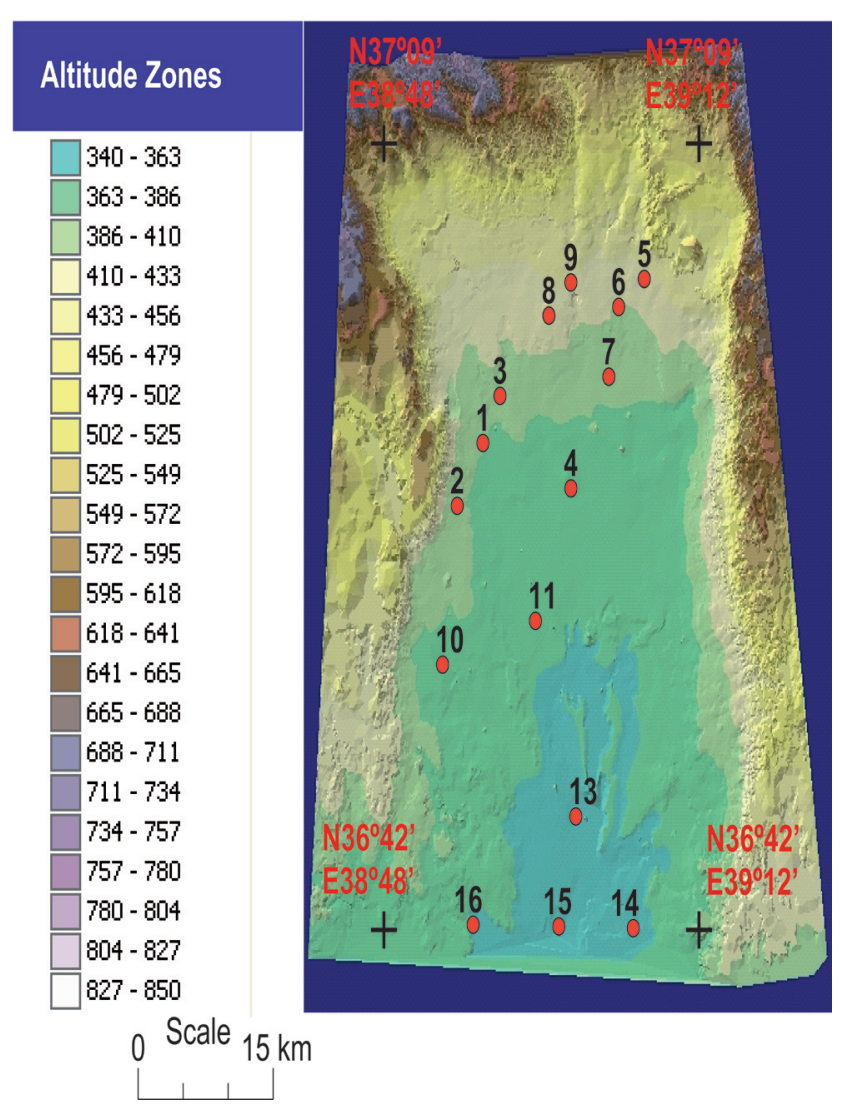

Fig. 1. Location of Harran Plain
(9), Harran (11), Kap (16), Sultantepe (3) and Sirrın (8) series are of the Aridisol soil order.

Rainfall is nonexistent during most of the year, and the climate is arid. According to 33 years of data (1975-2008) from the Turkish State of Meteorology Service (TSMS), the average annual precipitation is $277.8 \mathrm{~mm}$ at Akcakale station and $448.1 \mathrm{~mm}$ at Sanliurfa station. Specifically, while precipitation is low in Akcakale, the southernmost point, it reaches up to $450 \mathrm{~mm}$ on the northward foot of the Sanliurfa mountains. The soil moisture regime of important parts of the plain is Xeric, and the temperature regime is Mesic. Specifically, an Aridic soil humidity regime is seen in parts of the areas near the south of the plain (Soil Survey Staff, 1996).

In addition to being deficient in rain during most of year, the plain also experiences high temperatures for long periods of time. As Tab. 1 shows, there is little precipitation between May and October, and temperature and evaporation are high when rainfall is low. The evaporation rate increases from the foot of the Urfa mountains to Ak-

Tab. 1. Soil taxonomy of Harran Plain soils (SSS, 1975; FAO / UNESCO, 1974; Dinc et al., 1988)

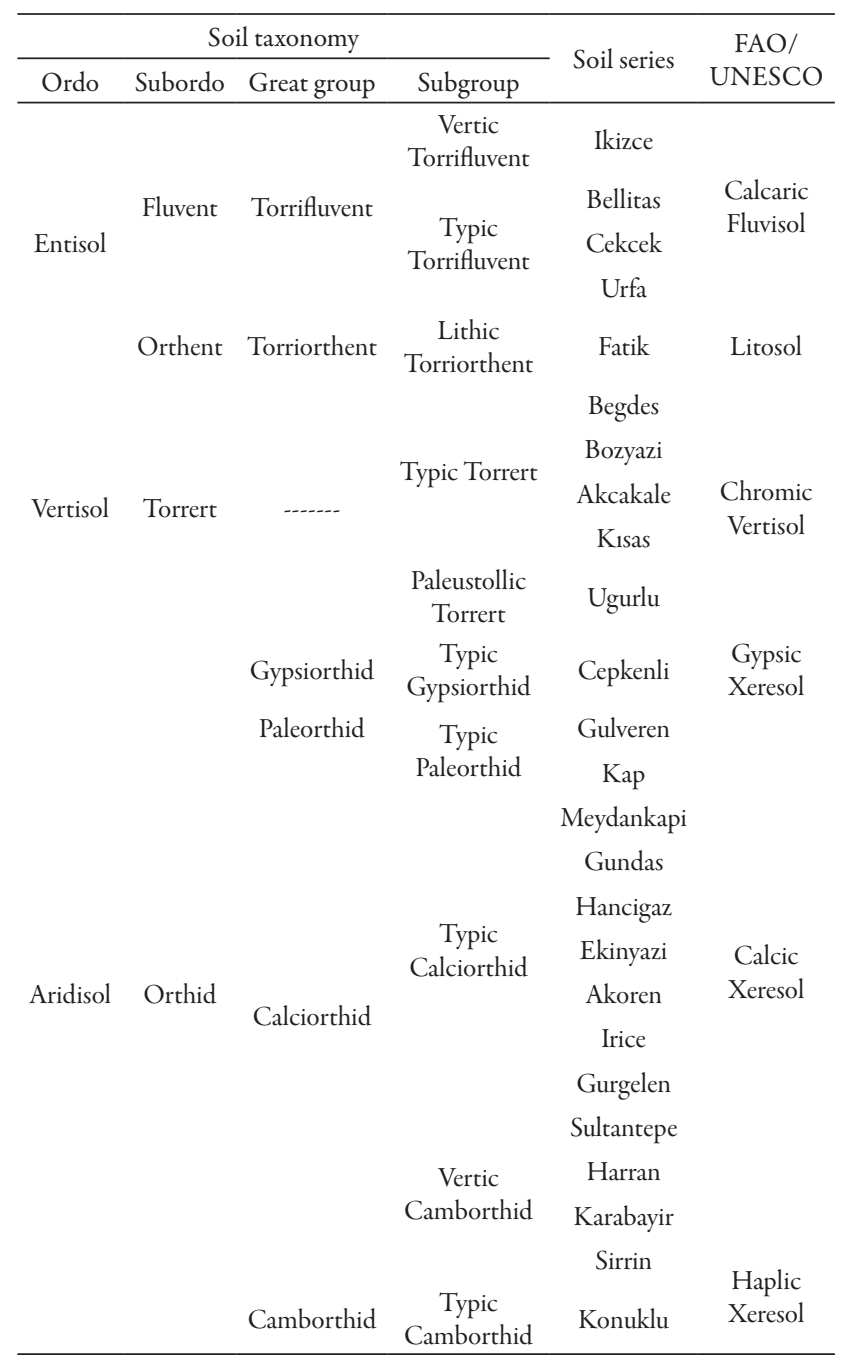


Tab. 2. Mean climate values of Sanliurfa and Akcakale stations (TSMS, 2008)

\begin{tabular}{|c|c|c|c|c|c|c|c|c|c|c|c|c|c|}
\hline & 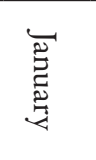 & $\begin{array}{l}\frac{T}{2} \\
\stackrel{0}{Z} \\
\stackrel{2}{2}\end{array}$ & $\begin{array}{l}\underset{2}{2} \\
\stackrel{2}{2} \\
\end{array}$ & 蛋 & $\underset{2}{2}$ & $\overleftrightarrow{\vec{\Xi}}$ & $\overline{\frac{E}{4}}$ & 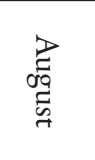 & 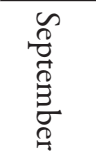 & $\begin{array}{l}0 \\
\hat{O} \\
\stackrel{0}{0} \\
\stackrel{0}{\oplus}\end{array}$ & 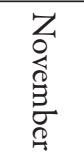 & 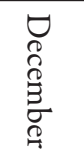 & $\frac{\gtrless}{\stackrel{2}{\overparen{2}}}$ \\
\hline Precipitation (mm) (Akcakale) & 47.39 & 45.83 & 40.46 & 27.56 & 17.24 & 0.99 & 0.81 & 0.47 & 18.79 & 33.05 & 47.38 & 47.39 & 277.81 \\
\hline $\operatorname{Precipitation}(\mathrm{mm})$ (Centre) & 77.21 & 78.36 & 65.55 & 44.41 & 27.51 & 3.52 & 0.79 & 1.06 & 0.91 & 27.58 & 49.88 & 75.31 & 448.11 \\
\hline Evaporation(mm) & - & - & 61.80 & 119.60 & 203.10 & 332.80 & 421.10 & 421.10 & 291.90 & 291.90 & 59.30 & - & 2022.80 \\
\hline Average Temperature $\left({ }^{\circ} \mathrm{C}\right)$ & 4.90 & 6.60 & 10.30 & 17.80 & 23.10 & 29.20 & 34.80 & 31.30 & 26.40 & 19.10 & 14.40 & 8.00 & 18.80 \\
\hline Minimum Temperature $\left({ }^{\circ} \mathrm{C}\right)$ & -2.40 & -1.50 & -0.60 & 6.10 & 10.60 & 18.50 & 22.70 & 20.40 & 13.80 & 9.40 & 5.70 & 1.00 & 8.650 \\
\hline Maximum Temperature $\left({ }^{\circ} \mathrm{C}\right)$ & 20.50 & 16.60 & 25.50 & 29.60 & 35.30 & 40.00 & 46.80 & 43.00 & 38.20 & 31.60 & 26.20 & 18.00 & 25.00 \\
\hline Average Relative Humidity (\%) & 74.30 & 63.00 & 55.20 & 56.80 & 41.00 & 36.70 & 33.40 & 43.00 & 46.10 & 54.40 & 52.90 & 71.70 & 52.40 \\
\hline $5 \mathrm{~cm}$ Average Soil Temperature $\left({ }^{\circ} \mathrm{C}\right)$ & 5.60 & 7.60 & 11.70 & 19.70 & 27.40 & 34.70 & 39.80 & 37.20 & 31.30 & 22.40 & 14.50 & 8.10 & 21.70 \\
\hline $10 \mathrm{~cm}$ Soil Temperature $\left({ }^{\circ} \mathrm{C}\right)$ & 6.00 & 7.60 & 11.40 & 19.20 & 26.10 & 32.50 & 37.40 & 35.80 & 30.80 & 22.80 & 15.30 & 8.60 & 21.10 \\
\hline
\end{tabular}

cakale. The seasonal average precipitation is highest in the winter months and lowest in the summer season.

Soil samples were taken from 16 series of genetic horizons on the Harran Plain. The soil samples were dried at room temperature and passed through a $2 \mathrm{~mm}$ sieve prior to analysis. The bulk density (BD) $\left(\mathrm{Mg} \mathrm{m}^{-3}\right)$ was determined according to Black (1965). The organic carbon content was estimated by titrating the samples boiled with sulphuric acid and $\mathrm{Fe}_{2} \mathrm{SO}_{4}$ (Walkely and Black, 1934). The SOC $\left(\mathrm{kg} \mathrm{C} \mathrm{m}^{-2}\right)$ stock was calculated according to Batjes (1996). The nitrogen content was analysed using the micro-Kjeldahl method (AOAC, 1990). The samples were read on a device that was set at $85^{\circ} \mathrm{C}$ (FP $\left.526 \mathrm{LC}, \mathrm{LECO}\right)$. The total nitrogen stock $\left(\mathrm{Kg} \mathrm{N} \mathrm{m}^{-2}\right)$ was computed with the method that was used for calculating the SOC stock. Student's t-test was used on all of the data comparisons and equation determinations and the data were examined at $\mathrm{p}<0.05$ and $\mathrm{p}<0.01$ significance levels.

\section{Results}

\section{Soil organic carbon stocks}

The SOC amounts and stocks, the $\mathrm{N}$ amount and stocks, and the BD were determined at $100 \mathrm{~cm}$ depths of Harran plain soils. The bulk density varied between 1.23$1.34 \mathrm{Mg} \mathrm{m}^{-3}$ (Tab. 3).

The SOC content was at its lowest in the Harran series $\left(3.57 \mathrm{~kg} \mathrm{C} \mathrm{m}^{-2}\right)$ and at its maximum level in the Sirrin series $\left(6.47 \mathrm{~kg} \mathrm{C} \mathrm{m}^{-2}\right)$. The total carbon amounts changed between 3.57 and $6.47 \mathrm{~kg} \mathrm{C} \mathrm{m}^{-2}$. The carbon amounts of the other series varied significantly $(p<0.05)$ and are shown in Tab. 4. The organic carbon stock of the Harran plain was $10.53 \mathrm{Tg}$ C. The organic carbon contents were higher on the northern side where precipitation was high. It is commonly known that, in general, temperature decreases as precipitation increases. High temperatures generally accelerate organic matter decomposition; hence, SOC decreases. Whereas the precipitation amount was $277 \mathrm{~mm}$ in the southern region, it was nearly $450 \mathrm{~mm}$ in the north. Therefore, carbon amounts were lower in the southernmost Akcakale series than in the northern Sirrin series. The carbon content of the plain was higher than that expected of an arid or semi-arid region because of in- creased soil depth, movement and accumulation of surface materials from high areas to the plain, high clay content (45-73\%), too much calcareousness, and the constant rejuvenation of the plain soils.

\section{Total nitrogen stocks}

The total nitrogen contents were between 0.72 and $1.07 \mathrm{~kg} \mathrm{~N} \mathrm{~m}^{-2}$, with the lowest content occurring in the Akcakale series and the highest content occurring in the Sirrin series. The nitrogen amounts of the other series are represented in Tab. 5. The total $\mathrm{N}$ stock was $1.96 \mathrm{Tg} \mathrm{N}$ on the Harran plain. The nitrogen content, like the carbon content, was higher in the northern profiles than in the southern profiles. It is hypothesised that the reason for this is high precipitation. Although it is known that the Harran plain soils are too clay, the effects of clay on nitrogen stocks are not known. There are no studies examining the texture-nitrogen relationship on the Harran plain. While it is estimated that when clay amount increases, nitrogen mineralization this phenomenon has not been confirmed. Generally, concentrations of nitrogen are high in areas where the SOC is high. This shows a positive C:N rela-

Tab. 3. Statistical distribution of bulk density $\left(\mathrm{mg} \mathrm{m}^{-3}\right)$

\begin{tabular}{ccccccc}
\hline Soil series $^{\mathrm{a}}$ & $\mathrm{N}$ & Mean & Minimum & Median & Maximum & $\mathrm{CV}^{\mathrm{b}}$ \\
\hline Ugurlu & 10 & 1.23 & 1.20 & 1.25 & 1.25 & 1.87 \\
\hline Cekcek & 10 & 1.27 & 1.25 & 1.26 & 1.29 & 1.30 \\
\hline Sultantepe & 10 & 1.30 & 1.27 & 1.30 & 1.32 & 1.38 \\
\hline Kisas & 10 & 1.29 & 1.27 & 1.29 & 1.31 & 1.15 \\
\hline Bellitas & 10 & 1.31 & 1.29 & 1.31 & 1.31 & 0.68 \\
\hline Bozyazi & 10 & 1.30 & 1.29 & 1.31 & 1.33 & 2.55 \\
İkizce & 10 & 1.30 & 1.28 & 1.29 & 1.31 & 1.04 \\
\hline Sirrin & 10 & 1.31 & 1.30 & 1.31 & 1.31 & 0.42 \\
\hline Irice & 10 & 1.30 & 1.28 & 1.29 & 1.31 & 1.04 \\
\hline Begdes & 10 & 1.32 & 1.30 & 1.33 & 1.33 & 1.25 \\
\hline Harran & 10 & 1.31 & 1.30 & 1.31 & 1.31 & 0.42 \\
\hline Gurgelen & 10 & 1.33 & 1.31 & 1.33 & 1.34 & 1.14 \\
Akoren & 10 & 1.34 & 0.75 & 1.33 & 1.34 & 1.35 \\
\hline Ekinyazi & 10 & 1.34 & 1.31 & 1.35 & 1.35 & 1.34 \\
Akcakale & 10 & 1.32 & 1.31 & 1.33 & 1.33 & 0.68 \\
\hline Kap & 10 & 1.34 & 1.33 & 1.34 & 1.34 & 0.33 \\
\hline
\end{tabular}

${ }^{a}$ Soil series are listed by Dinc et al. (1988); ${ }^{\mathrm{b}} \mathrm{CV}$ is the coefficient of variation (\%) 'Depth soil of $100 \mathrm{~cm}$; $\mathrm{N}$ is the number of observations 
Tab. 4. Carbon amounts of Harran plain soils $\left(\mathrm{kg} \mathrm{C} \mathrm{m}^{-2}\right)$

\begin{tabular}{ccccccc}
\hline Soil series $^{\mathrm{a}}$ & $\mathrm{N}$ & Mean & Minimum & Maximum & CV $^{\mathrm{b}}$ & $\begin{array}{c}\text { Total } \\
\text { SOC }^{\mathrm{c}}\end{array}$ \\
\hline Ugurlu & 10 & 1.14 & 0.78 & 1.47 & 22.38 & 4.62 \\
\hline Cekcek & 10 & 0.80 & 0.57 & 0.93 & 19.90 & 4.03 \\
\hline Sultantepe & 10 & 0.97 & 0.43 & 1.47 & 43.87 & 4.84 \\
\hline Kisas & 10 & 1.01 & 0.29 & 1.76 & 67.14 & 4.75 \\
Bellitas & 10 & 1.38 & 0.56 & 1.96 & 45.99 & 4.94 \\
\hline Bozyazi & 10 & 1.23 & 0.94 & 1.64 & 21.75 & 5.04 \\
\hline Ikizce & 10 & 1.44 & 0.79 & 1.98 & 39.71 & 5.22 \\
\hline Sirrin & 10 & 1.85 & 0.91 & 2.79 & 47.71 & 6.47 \\
\hline Irice & 10 & 1.54 & 1.21 & 1.86 & 19.76 & 5.85 \\
\hline Begdes & 10 & 1.16 & 0.34 & 1.98 & 69.40 & 5.45 \\
\hline Harran & 10 & 0.85 & 0.63 & 1.26 & 29.79 & 3.57 \\
Gurgelen & 10 & 0.87 & 0.58 & 1.21 & 32.33 & 3.78 \\
\hline Akoren & 10 & 1.00 & 0.89 & 1.21 & 12.17 & 4.06 \\
\hline Ekinyazi & 10 & 1.72 & 1.06 & 2.16 & 34.63 & 4.31 \\
\hline Akcakale & 10 & 1.26 & 0.80 & 1.46 & 20.81 & 3.61 \\
\hline Kap & 10 & 1.44 & 1.21 & 1.62 & 10.20 & 4.29 \\
\hline
\end{tabular}

${ }^{\mathrm{a}}$ Soil series are listed by Dinc et al. (1988); ${ }^{\mathrm{b}} \mathrm{CV}$ is the coefficient of variation

(\%); 'Depth soil of $100 \mathrm{~cm}$ total SOC; $\mathrm{N}$ is the number of observations

Tab. 5. Nitrogen content of Harran plain of soils $\left(\mathrm{kg} \mathrm{N} \mathrm{m}^{-2}\right)$

\begin{tabular}{ccccccc}
\hline Soils series $^{\mathrm{a}}$ & $\mathrm{N}$ & Mean & Minimum & Maximum & $\mathrm{CV}^{\mathrm{b}}$ & $\begin{array}{c}\text { Toplam } \\
\mathrm{N}^{\mathrm{c}}\end{array}$ \\
\hline Ugurlu & 10 & 0.21 & 0.14 & 0.28 & 24.13 & 0.85 \\
\hline Cekcek & 10 & 0.16 & 0.13 & 0.18 & 11.87 & 0.81 \\
\hline Sultantepe & 10 & 0.19 & 0.12 & 0.26 & 27.85 & 0.94 \\
\hline Kisas & 10 & 0.21 & 0.14 & 0.30 & 32.99 & 0.91 \\
\hline Bellitas & 10 & 0.25 & 0.10 & 0.35 & 45.74 & 0.88 \\
\hline Bozyazi & 10 & 0.29 & 0.16 & 0.28 & 19.80 & 0.94 \\
\hline Ikizce & 10 & 0.26 & 0.14 & 0.37 & 42.11 & 0.93 \\
\hline Sirrin & 10 & 0.32 & 0.15 & 0.49 & 51.30 & 0.97 \\
\hline Irice & 10 & 0.26 & 0.20 & 0.33 & 23.29 & 0.99 \\
\hline Begdes & 10 & 0.22 & 0.11 & 0.34 & 51.20 & 0.98 \\
\hline Harran & 10 & 0.19 & 0.11 & 0.25 & 27.57 & 0.73 \\
\hline Gurgelen & 10 & 0.18 & 0.14 & 0.24 & 23.97 & 0.76 \\
\hline Akoren & 10 & 0.20 & 0.17 & 0.23 & 11.75 & 0.78 \\
\hline Ekinyazi & 10 & 0.34 & 0.19 & 0.44 & 40.27 & 0.81 \\
\hline Akcakale & 10 & 0.26 & 0.15 & 0.30 & 24.79 & 0.72 \\
\hline Kap & 10 & 0.30 & 0.23 & 0.33 & 14.91 & 0.85 \\
\hline
\end{tabular}

${ }^{\mathrm{a}}$ Soil series are listed by Dinc et al. (1988); ${ }^{\mathrm{b}} \mathrm{CV}$ is the coefficient of variation (\%)

'Depth soil of $100 \mathrm{~cm}$ total $\mathrm{N}$; $\mathrm{N}$ is the number of observations

tionship. According to this relationship, clay decreases SOC oxidation. Hence, it is hypothesised that there could be a positive relationship between clay and nitrogen. Moreover, there is little effect of temperature and humidity parameters affecting carbon stocks on nitrogen stocks. However, to explain their relation with nitrogen, guesses are done related to their effects on carbon.

\section{Carbon/nitrogen $(C: N)$ ratios}

The carbon:nitrogen ratios were important $(\mathrm{p}<0.01)$ in all series throughout the profile $(100 \mathrm{~cm})$. The average
Tab. 6. C: $\mathrm{N}$ ratios of Harran plain soils $\left(\mathrm{kg} \mathrm{m}^{-2}\right)^{\mathrm{c}}$

\begin{tabular}{cccccc}
\hline Soil series $^{\mathrm{a}}$ & $\mathrm{N}$ & Mean & Minimum & Maximum & $\mathrm{CV}^{\mathrm{b}}$ \\
\hline Ugurlu & 10 & 5.48 & 5.22 & 5.75 & 4.06 \\
\hline Cekcek & 10 & 5.03 & 3.24 & 5.65 & 20.02 \\
\hline Sultantepe & 10 & 5.08 & 2.62 & 5.78 & 27.09 \\
\hline Kisas & 10 & 4.32 & 2.16 & 5.81 & 45.63 \\
\hline Bellitas & 10 & 5.64 & 5.58 & 5.78 & 1.38 \\
\hline Gurgelen & 10 & 5.17 & 4.27 & 5.81 & 15.97 \\
\hline Ikizce & 10 & 5.61 & 5.37 & 5.78 & 3.91 \\
\hline Sirrin & 10 & 6.04 & 5.75 & 6.30 & 4.43 \\
\hline Irice & 10 & 5.87 & 5.68 & 6.33 & 4.91 \\
\hline Begdes & 10 & 4.77 & 3.04 & 6.01 & 33.13 \\
\hline Harran & 10 & 4.70 & 3.56 & 5.71 & 22.97 \\
\hline Bozyazi & 10 & 4.80 & 4.01 & 5.58 & 15.18 \\
Akoren & 10 & 5.14 & 4.78 & 5.51 & 6.59 \\
\hline Ekinyazi & 10 & 5.25 & 4.91 & 5.75 & 8.77 \\
\hline Akcakale & 10 & 4.84 & 4.45 & 5.58 & 11.23 \\
\hline Kap & 10 & 4.80 & 4.37 & 5.71 & 12.90 \\
\hline
\end{tabular}

${ }^{\mathrm{a} S}$ Soil series are listed by Dinc et al. (1988); ${ }^{\mathrm{b}} \mathrm{CV}$ is the coefficient of variation (\%); 'Depth soil of $100 \mathrm{~cm}$; $\mathrm{N}$ is the number of observations

$\mathrm{C}: \mathrm{N}$ ratios of all of the series were ordered as follows: Sirrin $>$ Irice $>$ Bellitas $>$ Ikizce $>$ Begdes $>$ Ugurlu $>$ Gurgelen $>$ Ekinyazi $>$ Akoren $>$ Kisas $>$ Sultantepe $>$ Akcakale $>$ Kap $>$ Bozyazi $>$ Cekcek $>$ Harran (Tab. 6). The C:N ratios were generally high in areas where the altitude, the vegetation and the precipitation were high. The $\mathrm{C}: \mathrm{N}$ ratio was similar in the plain soils. This shows that the resolution and separation amounts are high. Moreover, the application of too much nitrogen fertiliser may have narrowed this ratio. A highly significant relationship existed between carbon and nitrogen contents $(r=0.9973$; $p<0.01)$ (Fig. 2).

The $\mathrm{C}: \mathrm{N}$ ratios ranged between $5.38: 1$ and $6.33: 1$ in surface soils $(0-20 \mathrm{~cm})$. There was not much variation among the $\mathrm{C}: \mathrm{N}$ ratios of the plain soils, which may be due to the similar climatic conditions and the agriculture management techniques adopted by the farmers. However, the small differences in the $\mathrm{C}: \mathrm{N}$ ratios may also be due to variations in the microclimatic conditions, especially the temperature and the quantity and distribution of precipitation.

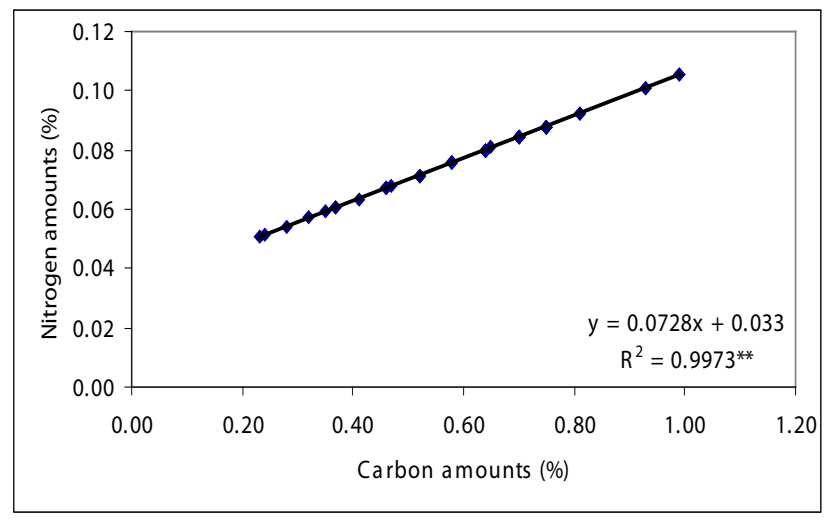

Fig. 2. Relationship between carbon and nitrogen 
108

\section{Discussion}

In this study, a small difference was observed between SOC and total $\mathrm{N}$ stocks and $\mathrm{C}: \mathrm{N}$ ratios of Harran Plain soils in the north-to-south direction. Average carbon stocks were slightly higher on the northern side than on the southern side, which may be due to higher precipitation on the northern portion than on the southern portion of the plain ( $450 \mathrm{~mm}$ vs. $277 \mathrm{~mm}$ ). Furthermore, high precipitation caused temperatures to decrease to some extent. This corroborates the observation that the SOC content decreases with increases in the annual temperature, as reported by Post et al. (1982), Tremblay et al. (2002), Ganuza and Almendros (2003), Lemenih and Itanna (2004), Wang et al. (2004) and Sakin (2010). According to Yimer et al. (2006) and Sakin et al. (2010a:b:c), the SOC stocks increase based on annual precipitation and biomass amounts and decrease relative to temperature. Soil C and $\mathrm{N}$ stocks are affected by climate (Post et al., 1982). In line with several earlier studies (Bationa and Buerkert, 2001; Yimer et al., 2006; Moges and Holden, 2008; Fu et al., 2010), a very strong relationship between $C$ and $N$ was observed in this study.

It is hypothesised that clay and calcareous plain soils retain high amounts of carbon and nitrogen, but there are different theories regarding the effect of the clay concentration in soil on the SOC accumulation. An increase in maximum and average SOC content with increased soil clay content has been reported from a few Great Plains sites (Nichols, 1984; Burke, 1989). However, this phenomenon cannot be generalised as other factors like soil aluminum, extractable allophone content or specific surface area can also influence the SOC content (Percival et al., 2000; Krull et al., 2003). The relationship between the clay concentration and the SOC content is strong when they are compared in soil organic matter (SOM) models like Century (Parton et al., 1987) and RothC (Jenkinson, 1990), which state that the SOM resolution decreases when the clay concentration increases. Wang et al. (2003) explains that clay has no effect on the first stage of soil occurrence but that it can be effective at the later stages. Muller and Hoper (2004) reveal the different effects of clay on carbon resolution. McLauchlan (2006) argues that no strong relationship between clay and carbon resolution has been observed.

The total $\mathrm{N}$ amounts and stocks are high on the northern portion of the Harran plain. The high nitrogen content is probably due to the high SOC content. The main reason for this is high precipitation; Ganuza and Almendros (2003) verify this theory. The clay content of the plain soil is high. Although the effect of clay on nitrogen stocks and amounts is unknown, a positive relationship is predicted. Some studies (Cote et al., 2000) state that the net N mineralisation decreases when the clay amount increases in the soil, but other studies (Giardina et al., 2001) have found that the effect of clay on the net $\mathrm{N}$ mineralisation is low under different temperature and humidity conditions in the laboratory. McLauchlan (2006) explains that when clay amounts increase in soil, aggregate amounts increase dramatically and the potential net $\mathrm{N}$ mineralisation decreases. Whatever the age of the field, each $10 \%$ increase in clay concentration increases the aggregate size index by 0.039 and decreases the net $\mathrm{N}$ mineralisation by $0.16 \mathrm{~kg}$ $\mathrm{ha}^{-1}$ day $^{-1}$.

The total nitrogen range $\left(0.72-1.07 \mathrm{~kg} \mathrm{~N} \mathrm{~m}^{-2}\right.$, in 100 $\mathrm{cm}$ depth) observed was similar to those observed in several previous studies. Carter et al. (1998) reported a total nitrogen range of $0.36-1.05 \mathrm{~kg} \mathrm{~N} \mathrm{~m}^{-2}$ in Canada farming soils. Zinke and Stangenberger (2000) found $0.61 \mathrm{~kg} \mathrm{~N}$ $\mathrm{m}^{-2}$ in Sierra shallow cone forests and $0.27 \mathrm{~kg} \mathrm{~N} \mathrm{~m}^{-2}$ in Nevada forests. Other nitrogen ranges observed include $0.5 \mathrm{~kg} \mathrm{~N} \mathrm{~m}^{-2}$ in mineral soils (Vejre et al., 2003), 0.21-3.13 $\mathrm{kg} \mathrm{N} \mathrm{m}^{-2}$ in Amazon soils (Dijkshoorn, 1999), $1.39 \mathrm{~kg} \mathrm{~N}$ $\mathrm{m}^{-2}$ in Podzol (Spodosol) soils, $1.03 \mathrm{~kg} \mathrm{~N} \mathrm{~m}^{-2}$ in Luvisoller (Alfisol) soils, $0.52 \mathrm{~kg} \mathrm{~N} \mathrm{~m}^{-2}$ in Arenosoller (Entisol) soils (Batjes, 1996), 0.17-0.29 kg N m${ }^{-2}$ (Fu et al., 2010) and $0.05-1.65 \mathrm{~kg} \mathrm{~N} \mathrm{~m}^{-2}$ (Callesen et al., 2007). According to Callesen et al. (2007), $\mathrm{N}$ is higher in calcareous soils (1.12 $\left.\mathrm{kg} \mathrm{N} \mathrm{m}^{-2}\right)$ than in fine-textured soils $\left(0.62 \mathrm{~kg} \mathrm{~N} \mathrm{~m}^{-2}\right)$ and medium-and coarse-textured soils $(0.51$ and $0.48 \mathrm{~kg} \mathrm{~N}$ $\mathrm{m}^{-2}$ ). In the research area, the Bellitas, Ikizce and CekCek series (Entisol) include, respectively, $0.81,0.88$ and 0.93 $\mathrm{kg} \mathrm{N} \mathrm{m}{ }^{-2}$; these amounts are high when compared with the Batjes (1996) studies and normal when compared with Batjes and Dijkshoorn (1999) study. It is hypothesised that this is based on high precipitation and soils that are calcareous and contain too much clay.

The C: $\mathrm{N}$ ratio in the surface soil was higher than that in lower portions of the subsurface soil horizons. This indicates high resolution and separation rates. Furthermore, it is thought that extreme cultivation techniques affect the $\mathrm{C}: \mathrm{N}$ ratios. The $\mathrm{C}: \mathrm{N}$ ratios varied between $4.86: 1$ and 6.02:1. Lal et al. (1995) indicated that $\mathrm{C}: \mathrm{N}$ ratios are low during resolution and separation times. Brady and Weil (2008) showed that $\mathrm{C}: \mathrm{N}$ ratios varied between 8:1 and $15: 1$, with an average of $12: 1$. Batjes (1996) determined (at a depth of $100 \mathrm{~cm}$ ) that the lowest average $\mathrm{C}: \mathrm{N}$ ratio was $7: 1$ in Xerosols and that the highest average $C: N$ was 24.5:1 in Podzols. Although the $\mathrm{C}: \mathrm{N}$ ratios in this study showed similarities to the Batjes (1996) findings, this study's ratios were lower. It is hypothesised that this phenomenon was caused by low precipitation, high resolution and separation rates and extreme cultivation techniques. Whereas the $\mathrm{C}: \mathrm{N}$ ratio increases with precipitation, it decreases with higher temperatures (Miller et al., 2004). Other researchers argue that there is a positive relationship between $\mathrm{C}: \mathrm{N}$ ratios, precipitation and temperature (Callesen, 2007). It is argued that although the cultivation systems and farming activities used 10 years ago did not affect C:N ratios (Sainju et al., 2008; Fu et al., 2010), today's farming techniques and agriculture do affect $\mathrm{C}: \mathrm{N}$ ratios (Puget and Lal, 2005; Yimer et al., 2007). 


\section{Conclusions}

Carbon amounts and stocks, $\mathrm{N}$ amounts and stocks and $\mathrm{C}: \mathrm{N}$ ratios of plain soils are generally higher than similar environments. The reasons for the high $\mathrm{C}$ and $\mathrm{N}$ contents are precipitation, high clay and calcareous contents, soil depths, material movement from high areas to the plains and soil regeneration. The close $\mathrm{C}: \mathrm{N}$ ratios are based on high resolution and separation amounts because of high temperatures, oxidation and fertiliser usage by farmers, which contain high levels of nitrogen.

\section{References}

Aber, J. D., K. J. Nadelhoffer, P. Steudler, and J. M. Melillo. 1989. Nitrogen Saturation in Northern Forest Ecosystems. BioScience 39(6):378-386.

AOAC. Official methods of analysis, $15^{\text {th }}$ ed. Association of Official Analytical Chemistry, Washington, D.C.

Bationo, A. and A. Buerkert (2001). Soil organic carbon management for sustainable land use in Sudano-Sahelian West Africa. Nutr. Cycl. Agroecosys 61:131-142.

Batjes, N. H. and J. A. Dijkshoorn (1999). Carbon and nitrogen stocks in the soils of the Amazon Region. Geoderma 89:273286.

Batjes, N.H. (1996). Total carbon and nitrogen in the soils of the world. European J Soil Sci 47:151-163

Brady, C and R. R. Weil (2008). The nature and properties of soils. 14 $4^{\text {th }}$ ed. Pearson Prentice hall. Upper Saddle River, New Jersey Columbus, Ohia, USA.

Burke, I. C., C. M. Yonker, W. J. Parton, C. V. Cole, K. Flach and D. S. Schimel (1989). Texture, climate, and cultivation effects on soil organic matter content in U.S. grassland soils. Soil Sci Soc Am J 53:800-805.

Callesen, I., K. R. Rasmussen, C. J. Westman, and L. Tau-Strand (2007). Nitrogen pools and C:N ratios in well-drained Nordic forest soils related to climate and soil texture. Boreal Environment Research 12:681-692.

Carter, M. R., D. A. Angers, E. G. Gregorich and M. A. Bolinder (1998). Organic carbon and nitrogen stocks and storage profiles in cool, and humid, soils of eastern Canada. Can. J. Soil Sci. 77:205-210.

Conant, R. T., J. M. Klopatek, R. C. Malin and C. C. Klopatek (1998). Carbon pools and fluxes along an environmental gradient in northern Arizona. Biogeochemistry 43:43-61.

Eaton, J. M., N. M. McGoff, K. A. Byrne, P. Leahy and G. Kiely (2008). Land cover change and soil organic carbon stocks in the Republic of Ireland. Clim. Change 91:317-334.

Fu, X., M. Shao, X. Wei and R. Horton (2010). Soil organic carbon and total nitrogen as affected by vegetation types in Northern Loess Plateau of China. Geoderma 155: 31-35.

Franzmeier, D. P., G. D.Lemme and R. J. Miles (1985). Organic carbon in soils of north central United States. Soil Sci Soc Am J 49:702-708.

Ganuza, A. and G. Almendros (2003). Organic carbon storage in soils of the Basque Country (Spain): the effect of climate,
109

vegetation type and edaphic variables. Biol. Fertil. Soils 37:154-162.

Grandy, A. S. and G. P. Robertson (2007). Land-use intensity effects on soil organic carbon accumulation rates and mechanisms. Ecosystems 10:58-73.

Grigal, D. F. and L. F. Ohmann (1992). Carbon storage in upland forests of the Lake States. Soil Sci Soc Am J 56:935-943.

Hontoria, C., J.C. Rodriguez-Murillo and A. Saa (1999). Relationships between soil organic carbon and site characteristics in peninsular Spain. Soil Sci Soc Am J 63:614-621.

Homann, P. S., J. S. Kapchinske and A. Boyce (2007). Relations of mineral-soil $\mathrm{C}$ and $\mathrm{N}$ to climate and texture: regional differences within the conterminous USA. Biogeochemistry 85:303-316.

Homann, P. S., S. M. Remillard, M. E. Harmon and B. T. Bormann (2004). Carbon storage in coarse and fine fractions of Pacific Northwest old-growth forest soils. Soil Sci Soc Am J 68:2023-2030.

Homann, P.S., R. B. McKane and P. Sollins (2000). Belowground processes in forest-ecosystem biogeochemical simulation models. Forest Ecol Manage 138:3-18

Homann, P.S., P. Sollins, H. N. Chappell and A. G. Stangenberger (1995). Soil organic carbon in a mountainous, forested region: relation to site characteristics. Soil Sci Soc Am J 59:1468-1475.

Jenny, H. (1941). Factors of soil formation. McGraw Hill, NY.

Jenkinson, D. S. (1990). The turnover of organic carbon and nitrogen in soil. Philosophical Transactions: Biological Sciences 329:361-367.

Kirschbaum, M. U. F . (2000). Will changes in soil organic carbon act as a positive or negative feedback on global warming? Biogeochemistry 48:21-51.

Krull, E. S., J. A. Baldock and J. O. Skjemstad (2003). Importance of mechanisms and processes of the stabilisation of soil organic matter for modelling carbon turnover. Functional Plant Biology 30(2):207-222.

Lal, R., J. Kimble and B. A. Stewart (1995). World Soils as a or sink for radio-active gases. 1-7 pp. In: Soil management and greenhouse effect, B.B. Jørgensen (Eds.). Lewis, London.

Lemenih, M. and F. Itanna (2004). Soil carbon stock and turnovers in various vegetation types and arable lands along an elevation gradient in southern Ethiopia. Geoderma 123:177-188.

Liski, J. and C. J. Westman (1997). Carbon storage in forest soil of Finland. 1. Effect of thermoclimate. Biogeochemistry 36:239-260.

Mäkipää, R., T. Karjalainen, A. Pussinen and S. Kellomäki (1999). Effects of climate change and nitrogen deposition Forest floor chemissequestration of a forest ecosystem in the boreal zone. Can. J. Res. 29:1490-1501.

McLauchlan, K. K. (2006). Effect of soil texture on soil carbon and nitrogen dynamic after cessation of agriculture. Geoderma 136:289-299.

Melillo, J. M. (1981). Nitrogen Cycling in Deciduous 
110

Forests,427-442 pp. In: Terrestrial nitrogen cycles. Process, ecosystem strategies, and management impacts.Clark, F. E. and T. Roswall (Eds.). Ecological Bulletin 33, Swedish Natural Science Research Council, Stockholm.

Miller, A. J., R. Amundson, I. C. Burke and C. Yonker (2004). The effect of climate and cultivation on soil organic $\mathrm{C}$ and N. Biogeochemistry 67:57-72.

Moges, A. and N. M. Holden (2009). Soil fertility in relation to hillslope position and agricultural land use: a case study of Umbulo Catchment in southern Ethiopia. Environ. Manage. 42 :753-763.

Muller, T. and H. Hoper (2004). Soil organic matter turnover as a function of the soil clay content: consequences for model applications. Soil Biology and Biochemistry 36:877-888.

Nichols, J. D. (1984). Relation of organic carbon to soil properties and climate in the southern Great Plains. Soil Science Society of America Journal 48:1382-1384.

Paruelo J. M., E. G. Jobba'gy, O. E. Sala, W. K. Lauenroth and I. C. Burke (1998). Functional and structural convergence of temperate grassland and shrubland ecosystems. Ecol. Applic. 8:194-206.

Parton, W. J., D. S. Schimel, C. V.Cole and D. S. Ojima (1987). Analysis of factors controlling soil organic matter levels on Great Plains grasslands. Soil Science Society of America Journal 51:1173-1179.

Pepper, D. A., S. J. Del Grosso, R. E. McMurtrie and W. J. Parton (2005). Simulated carbon sink response of shortgrass steppe, tallgrass prairie and forest ecosystems to rising $\left[\mathrm{CO}_{2}\right]$, temperature and nitrogen input. Global Biogeochem Cycles 19(GB1004):1-20.

Percival, H. J., R .L. Parfitt and N. A. Scott (2000). Factors controlling soil carbon levels in New Zealand grasslands: is clay content important? Soil Science Society of America Journal 64(5):1623-1630.

Post, W. M., W. R. Emanuel, P. J. Zinke and A. G. Stangenberger (1982). Soil carbon pools and world life zones. Nature 298:155-159.

Post, W. M. and K. C. Kwon (2000). Soil carbon sequestration and land-use change: processes and potential. Global Change Biol. 6:317-327.

Puget, P., and R. Lal (2005). Soil organic carbon and nitrogen in a Mollisol in central Ohio as affected by tillage and land use. Soil Tillage Res. 80:201-213.

Powers, J. S. (2004). Changes in soil carbon and nitrogen after contrasting land-use transitions in northeastern Costa Rica. Ecosystems 7:134-146.

Rodríguez-Murillo, J. C. (2001). Organic carbon content under different types of land use and soil in peninsular Spain. Biol. Fertil. Soils 33:53-61.

Sainju, U. M., Z. N. Senwo, E.Z. Nyakatawa, I. A. Tazisong and K .C. Reddy (2008). Soil carbon and nitrogen sequestration as affected by long-term tillage, cropping systems, and nitrogen fertilizer sources. Agric. Ecosyst. Environ. 127:234-240.

Sakin, E., A. Deliboran, E. D. Sakin, and E. Tutar (2010)a. Organic and inorganic carbon stocks and balance of Adana city soils in Turkey. African J Agric. Res. 5(19):2737-2743.
Sakin, E., A. Deliboran, E. D. Sakin, and E. Tutar (2010)b. Bulk density of Harran Plain soils in relation to other soil properties. African Journal Agricultural Research (In press).

Sakin, E. (2010). Carbon stocks and balance soils of Southeast Anatolia Region. Natural Application Inst. of Harran Univ. Sanliurfa, Ph. D. Thesis.

Sakin, E., A. Deliboran, E. D. Sakin, and E. Tutar (2010)c. Carbon Stocks in Harran Plain Soils, Sanliurfa, Turkey. Notulae Botanicae Horti Agrobotanici Cluj-Napoca 38(3):151-156.

Schlesinger, W. H. (1997). Biogeochemistry, an analysis of global change, 2nd edn. Academic Press, New York.

Sims, Z. R. and G. A. Nielsen (1986). Organic carbon in Montana soils as related to clay content and climate. Soil Sci. Soc. Am. J. 50:1269-1271.

Smith, P., D. Martino, Z. Cai, D. Gwary, H. Janzen, P. Kumar, B. McCarl, S. Ogle, F. O’Mara, C. Rice, B. Scholes, O. Sirotenko, M. Howden, T. McAllister, G. Pan, V. Romanenkov, U. Schneider and S. Towprayoon (2007). Policy and technological constraints to implementation of greenhouse gas mitigation options in agriculture. Agric. Ecosyst. Environ. 118:6-28.

Smith, P. (2008). Land use change and soil organic carbon dynamics. Nutr. Cycl. Agroecosys. 81:169-178.

Spain, A. V. (1990). Influence of environmental conditions and some soil chemical properties on the carbon and nitrogen contents of some tropical Australian rainforest soils. Aust. J. Soil Res. 28:825-839.

Solomon, D., J. Lehmann and W. Zech (2000). Land use effects on soil organic matter properties of chromic luvisols in semi-arid northern Tanzania: carbon, nitrogen, lignin and carbohydrates. Agric. Ecosyst. Environ. 78:203-213.

Turkish State Meteorological Service (2008). Data of Climate Sanliurfa and Akcakale stations. Meteorological Bulten, Ankara.

Tremblay, S., R. Ouimet and D. Houle (2002). Prediction of organic carbon content in upland forest soils of Quebec, Canada. Can. J. For. Res. 32:903-914.

Wang, W. J., R. C. Dalal, P. W. Moody and C. J. Smith (2003). Relationships of soil respiration to microbial biomass, substrate availability and clay content. Soil Biology and Biochemistry 35(2):273-284.

Wang, S., M. Shao, R. Mickler and K. J. Ji (2004). Vertical distribution of soil organic carbon in China. Environ. Manage. 33(Supplement):200-209.

Yimer, G., S. Ledin and A. Abdelkadir (2006). Soil organic carbon and total nitrogen stocks as affected by topografic aspect and vejetation in the Bale Mountains, Ethiopia. Geoderma 135:335-344.

Yimer, F., S. Ledin and A. Abdelkadir (2007). Changes in soil organic carbon and total nitrogen contents in three adjacent land use types in the Bale Mountains, southeastern highlands of Ethiopia. Fores. Ecol. Manage. 242:337-342.

Zinke, P. J. and A. G. Stangenberger (2000). Elemental storage of forest soil from local to global scales. For. Ecol. Manage. 138:159-165. 